\title{
Opmerkings rondom die basiese probleem van die Teologiese Etiek
}

\author{
B J ENGELBRECHT
}

\section{Aan my vriend, $P$ S Dreyer}

Tydens die feesvoordragte toe die teologiese vereniging Van der Hoff vyftig jaar oud was in 1976 het ek ' $n$ ongepubliseerde referaat oor bortaande onderwerp voor die Predikantevergadering gelewer. Gedurende die bespreking van die voordrag was daar egter broeders wat gemeen het dat die basiese probleem van die Christelike Etiek'n ander was as dié wat ek daar aan die orde gestel het. Intussen het dié saak my egter telkens weer geïnteresseer en het dit meer as een keer in my lesings aan die Universiteit te berde gekom.

Nou het daar in 1976 ' $n$ boek verskyn wat as die basiese probleem van die Christelike Etiek presies dié saak aanstip en behandel wat in die genoemde lesing en besinning ter sprake gekom het. Die naam van hierdie publikasie is Bible and Ethics in Christian Life (221 pages, Augsburg Publishing House, Mineapolis 1976) deur die Bybelwetenskaplike, Bruce C Birch en die Christelike etikus, Larry L Rasmussen.

In sy algemeenste vorm kan ons die basiese probleem van die Christelike Etiek soos volg formuleer: Wat is die verhouding tussen die Bybel én die etiese besluitneming en gevolglik die sedelike lewe (van die gelowige óf van die mens en maatskappy in die algemeen)? Dit is veral 'n probleem van die Protestantisme omdat die formele beginsel van die Protestantisme (geformuleer deur Dorner. Das Prinzip unsrer Kirche, 1841 en Schweizer, Glaubenslehre der Evangelish-Reformierten Kirche, 1844 en wat "uit die loutere Evangelie geput is") die volgende is: "Die Heilige Skrif is die enigste maatstaf vir ons geloof en lewe". Dit kom byvoorbeeld duidelik na vore in die Tweede Helvetiese Konfessie, Hoofstuk I, 3 waar ons lees:

"Sentimus ergo, ex hisce Scripturis petendam esse veram sapienthiam et pietatem, ecclesiarum quoque reformationem et gubernationem, omniuque officiorum pietatis institutionem, probationem denique dogmatum reprobationemque aut errorum confutationem omnium ..."

Veral die sinsnedes dat "die ware wysheid en vroomheid" ("vera sapientia et pietas") én "die onderrig in vroomheid" ("institutio pietatis") "in hierdie Skrifte gesoek moet word", is tiperend van die instelling van die hele Reformasie ten opsigte van die verhouding: Bybel/sedelike lewe. 
Maar alreeds vir die Reformatore het dit duidelik geword dat die materiële uitvoering van hierdie pragtige formele program om die lig van Gods Woord op alle fasette van alle lewensterreine te laat val (om te bepaal wat goed en wat sleg is), nie so'n eenvoudige saak was nie. Aan die een kant het daar vrae ontstaan soos: Hoe moet die Bybel en veral gebooie en verbooie presies uitgelê word? Dra alle dele van die Bybel eweveel gewig? Is daar kultuurgebonde en situasiegebonde uitsprake in die Bybel wat vandag minder of geen gewig dra nie? Wat is die verhouding tussen wet en evangelie? Aan die ander kant is vanuit die werklikheid gevra: Watter dele van die Bybel is relevant ten opsigte van 'n bepaalde saak? Is daar lewensgebiede wat ten opsigte van God se Woord eties neutraal is sodat van adiaphora gepraat kan word, dit wil sê sake wat nie goed of sleg is in etiese sin nie? Praat die Bybel werklik oor alle lewenssituasies? Ook oor al die fasette van die moderne lewensproblematiek?

Telkens is die probleme rondom die verhouding "Bybel/sedelike lewe" verskerp, eerstens deur die ontwikkeling van die Bybelwetenskap én tweedens deur die toenemende gekompliseerdheid van die lewe. Birch en Rasmussen wys daarop dat daar vandag by die Bybelwetenskaplike ' $n$ frustrasie is wanneer hy na die hantering van "Bybelse gegewens" in die Christelike Etiek kyk. Dikwels voel hy dat die Bybel in die Christelike Etiek gemanipuleer word; dat daar gesê word dat dié Etiek "Bybels" is, maar in feite maak die werklike eksegese weinig verskil aan wat volgens die Christelike Etiek geoorloof is of nie. Aan die ander kant is daar ook by die Christelike etici frustrasies wanneer Bybelwetenskaplikes hulleself as historici of super-gespesialiseerde literêre tegnici beskou wat weinig verband het met die alledaagse werklikheid en etiese besluitneming. En intussen is daar ' $n$ honger by gelowiges (en dikwels ook by ongelowiges) na duidelike etiese leiding en voorligting, veral uit 'n werklik outoritatiewe bron. Hierdie omstandighede maak dit dringend noodsaaklik om die hele saak van "a functional relating of the Bible and ethics in Christian life" (Birch etc, p 12) noukeurig te deurdink. Dit sal moet gaan oor 'n opklaring van "the whole range of component elements in relating Christian ethnics and biblical materials" (p 19). As die Bybel nie meer "somehow normative for Christian ethics" is nie (p 46), dan verval die hele Reformatoriese beginsel van die Skrif as norm vir ons geloof en lewe.

Die eerste probleemkompleks wat na vore tree wanneer ons die Bybel met ons lewe en etiese besluitneming in verband wil bring, ontstaan rondom die historiese materiaal van die Bybel.

Die feit dat Salomo 700 vroue en 300 bywywe gehad het, staan ook in die Bybel (I Kon 11:3), is ook Woord van God en deel van die Heilige Skrif. Die vraag is nou: Hoe moet ons hierdie gedeelte van God se Woord toepas op ons lewe om leiding aan ons keuses en be- 
slissings te gee, in hierdie geval ten opsigte van die huwelik? Geen verantwoordelike Christelike etikus sal dié gedeelte op dié wyse toepas dat dit die normatiewe voorbeeld van poligamie is, ook vir vandag nie. Veeleer sal van hierdie geskiedenis se toepassing op vandag geld wat 1 Korintiërs 10 vers 11 van sommige Ou-Testamentiese geskiedenisse sê, naamlik dat hulle "as voorbeelde gebeur het en opgeskrywe is as 'n waarskuwing vir ons ...". Dit is egter duidelik dat die blote geskiedkundige feit dat Salomo so baie vroue en bywywe gehad het, nie as sodanig voorbeeld en waarskuwing is nie. Eers wanneer so ' $n$ historiese feit (wat in sigself stom is) geïnterpreteer word, soos wat I Konings 11 vers 3-13 met I Konings 11 vers 1-3 doen, kan dit as voorbeeld en waarskuwing vir ons situasie dien. Daaruit blyk dat hierdie talle vroue Salomo tot afgodery verlei het. $G C$ van Niftrik het van die Nuwe-Testamentiese getuienis aangaande Jesus Christus gesê dat dit nooit bloot ' $n$ historiese feit stel nie, maar dat dit altyd gaan om die "factum sámen mét de interpreterende verkóndiging van dit factum", altyd om "factum plús interpretatie" (Kleine Dogmatiek, 4de druk 1953, bl 128-129). In ons verband wil ons na analogie van bostaande aanhaling stel: Voordat ons historiese materiaal van die Bybel gebruik om as norm te dien vir ons lewe vandag, moet ons nie net die historiese feitelikheid in aanmerking neem nie, maar ook die interpretasie daarvan in die Bybel. Partymaal sal "de interpreterende verkondiging" in dieselfde hoofstuk of Bybelboek gevind word, (soos in verband met I Konings 11 vers 1-3), maar dikwels sal die werklike interpretasie van 'n bepaalde Bybelgeskiedenis eers in Bybelboeke gevind word wat eeue ná hierdie geskiedenis geskryf is. Dit is duidelik dat agter so 'n prosedure allerlei sake soos die beskouing oor die aard en eenheid van die Skrif én oor hermeneutiese beginsels wat op die spel is en die metodes wat gebruik word, sal lê.

Keer ons weer ' $n$ keer terug na die poligamie van Salomo waarvan I Konings 11 vers 1-3 die feit stel en wat I Konings 11 vers 4-13 beoordeel, dan sien ons dat die "interpreterende verkondiging" in hierdie geval nie poligamie as sodanig afkeur nie, maar slegs die verderflike gevolge van die bepaalde soort poligamie in Salomo se geval aanstip. Hy het naamlik toegegee aan die wense van al "sy uitlandse vroue wat rook laat opgaan het en geoffer het aan hulle gode" (vers 8). Sy oortreding volgens I Konings 11 was nie soseer poligamie nie, maar dat "Salomo baie uitlandse vroue liefgehad het . . . uit die nasies waarvan die HERE aan die kinders van Israel gesê het: Julle mag nie met hulle meng nie, en hulle mag nie met julle meng nie; hulle sal voorwaar julle hart verlei, agter hulle gode aan ..." (vers 1 en 2; sien ook vers 10 ). Daarom sal ons, as ons werklik poligamié vanuit die Bybel wil beoordeel, na verdere "interpreterende verkondiging" oor dié saak in die Bybel moet gaan soek. Dit word duidelik dat ons die 
hele leer van die Bybel oor die huwelik ter sprake sal moet laat kom soos byvoorbeeld:

die "monogame" veronderstelling wanneer die verhouding tussen God en sy volk in beide Ou en Nuwe Testament met die huwelik vergelyk word, en veral . . .

die direkte leeruitsprake in dié verband soos die uitspraak van Jesus in Matteus 19 vers 8 dat poligamie en egskeiding nie in die oorspronklike bedoeling van God gelê het toe Hy vir Adam één vrou en vir Eva één man geskape het nie (Gen 1: 27-28).

Die voorbeeld van die poligamie van Salomo is gekies omdat dit maklik verstaanbaar is, aangesien dit so'n ekstreme en enkelvoudige geval is. Gewoonlik is dié sake wat in die Christelike Etiek opgeklaar moet word en wat duisende mense se lewe én gewete voor God raak, oneindig ingewikkelder. Maar dit het duidelik geword dat die hantering van die historiese materiaal van die Bybel 'n saak is wat groot noukeurigheid en tegelyk groot verantwoordelikheid en versigtigheid vra. Dit is goed om in hierdie verband te onthou wat Richard $C$ Ondersluys gesê het:

"Moreover, the assumption that everything that happened then, must happen now, is altogether unwarranted. Everything in the Bible is authorotative but not all is normative. Some things happened then which ought not to have happened, and other things happened once and were never meant to happen again" (In: Reformed Review, Autumn 1974, Vol 28, No 1, p 51).

Vir die hantering van die "historiese stof" van die Bybel binne Christelik-Etiese konteks, wil ons in die lig van bostaande die volgende riglyne gee:

Die "historiese stof" moet noukeurig gesien word in die literêre, saaklike, historiese en kultuurhistoriese verbande waarin dit staan;

nadat dit "verstaan" is, moet dit geplaas word in die verband van "de interpreterende verkondiging" ten opsigte van dié aangeleentheid wat ter sprake is;

die aard van die verband tussen "historiese stof" en "interpreterende verkondiging" moet sodanig wees dat die direkte leeruitsprake (wat natuurlik óók noukeurig geëksegetiseer moet word), dit wil sê die direktiewe, die historiese stof moet belig en nie andersom nie. Nie die geskiedenis nie, maar die direktief is normatief;

deur die eeue heen is daar, ten minste wat die gebruiklike en sentrale probleme en probleemkomplekse in die Christelike 
Etiek aangaan, vasgestel watter stof van die Bybelse geskiedenis én van "de interpreterende verkondiging" relevant is ten opsigte van die spesifieke probleem en probleemveld. Van hieruit is daar dan ook pleidooie gelewer vir "kodifisering" en "katalogisering" byvoorbeeld op die wyse van die kasuïstiek óók in die Protestantse Etiek. In elk geval: Die Christelike etikus kan maklik self kontroleer of die gebruiklike Bybelse materiaal ten opsigte van ' $n$ bepaalde probleem nog relevant is in die lig van die hedendaagse resultate van die Teologiese Eksegese in die bepaalde verband. Hy sal egter nie maklik kan vasstel wanneer op grond van nuwere eksegetiese metodes daar nuwe relevante materiaal ten opsigte van ' $n$ bepaalde teologies-etiese probleem of probleemveld na vore kom nie. In hierdie opsig sal dit dan die taak van die Bybelwetenskaplike wees om op effektiewe wyse hierdie inligting aan die Christelike etikus beskikbaar te stel.

Die tweede probleemkompleks wat rondom die program om die Bybel relevant te laat wees vir die etiese beslissings en lewe van die gelowiges, ontstaan wanneer dit duidelik word dat die Bybel nie direk praat oor baie sake, aktiwiteite, probleme en probleemvelde van die moderne lewe en samelewing nie. Die Reformatoriese ideaal is: "Om die lig van Gods Woord te laat val oor alle sake van alle lewensterreine om te bepaal wat goed is of sleg voor God, wat geoorloof is of verbode volgens sy Woord". In Psalm 119 vers 7 lees ons: "Waarmee sal die jongeling sy pad suiwer hou? Deur (dit) te hou na u woord". Die Reformatore wil hierdie Bybelse uitspraak ten opsigte van die lewenswandel van die jeug toepas op alle lewensuitinge van alle mense onder alle lewensomstandighede. Die eerste vraag is nou: "Hoe laat 'n mens die lig van Gods Woord val op 'n lewensterrein?" en die tweede vraag (wat nou met die eerste vraag kan saamhang) is: "Hoe laat ons die lig van Gods Woord op alle lewensterreine val, veral op die hedendaagse etiese problematiek wat nie direk in die Bybelse tyd bekend was en ter sprake gekom het nie?"

Dit is opvallend dat ' $n$ hele aantal publikasies vandag in die beantwoording van albei bogenoemde vrae in ' $n$ bepaalde rigting beweeg. Die genoemde boek van Birch en Rasmussen stel dat daar in die etiek onderskeid gemaak moet word tussen die element van vorming van 'n lewensbeskouing en karakter, (the ethics of being") en die element van besluitneming en daad, ("the ethics of doing"). Die mens moet wel goeie dade doen, maar belangriker is om 'n goeie mens te wees. Nou is dit waar dat die Bybel wel sekere voorskrifte gee waarvolgens die mens goeie dade moet doen, maar"the most effective and crucial impact of the Bible in Christian ethics is that of shaping the moral identity of the Christian and of the church" ( $\mathrm{p}$ 104). Hierdie benadering 
sluit natuurlik baie nou aan by die talle Nuwe-Testamentiese gedeeltes oor:

die boom en sy vrugte;

die "nuwe" mens of "nuwe" skepsel én

by gedeeltes met die strekking van Lukas 6 vers 45 : "Die goeie mens bring uit die goeie skat van sy hart te voorskyn wat goed is; en die slegte mens bring uit die slegte skat van sy hart te voorskyn wat sleg is; want uit die oorvloed van die hart spreek die mond". Daar is dus 'n onderskeid tussen "die hart" en "die skat van die hart". Hierdie "skat van die hart" is die somtotaal van die duisende indrukke wat van buite af in die hart inkom en tot op groot hoogte die mens se doen en late bepaal. Die "skat van die hart" sal goed wees en "wat goed is, te voorskyn bring", indien "jou oog reg is" (Matt 6:19 v v), indien jou lewens- en wêreldbeskouing reg is, dit wil sê indien dit gevorm is deur die beelde en veral deur die waardes en prioriteite wat die Bybelse boodskap stel ... Hierdie benadering sluit nou aan by die holistiese beskouing van die Bybel soos ons dit onder andere in die resente publikasies van Brevard Childs met sy "teologiese eksegese" kry en ook by J $A$ Sanders. Dit is duidelik dat bostaande benadering inhou dat die hele Bybel (en nie net of slegs nie veral die sogenaamde etiese gedeeltes nie) vir alle fasette van alle lewensterreine relevant is. Ook die probleem van die adiaphora word hierdeur uitgeskakel, want nou verval die hele aangeleentheid van terreine waarvan gemeen is dat hulle Christelik-eties indifferent is en dat dit nie nodig is om Gods Woord daarop te laat val nie, byvoorbeeld watter pak klere moet ek vandag aantrek, watter motorvoertuig moet ek koop, ens.? Indien die "skat van die hart" (ook: "die hart", "die boom") goed is, dan kan ook "of ons eet en drink of enigiets wat ons doen", "alles gedoen word tot verheerliking van God" (I Kor 10:31). Ook N H Soë los die probleem van die adiaphora in hierdie rigting op en konkludeer:

"Entscheidend ist, dass man sich immer neu einschärfen lässt dass das ganze Leben des Christen (und damit selbsverständlich auch sein Verhältnis zu den sogen. Adiaphora unter Herrschaft des Geistes Gottes kommen muss" (Christliche Ethik, 1949, bl 160-166).

Die etiese rigting van Birch en Rasmussen staan bekend in die rigting van die "disposisionele etiek". Dit sluit nou aan by Luther wat gestel het dat afsonderlike dade net etiese waarde het as dit in verband staan met die fundamentele disposisie, die geloof in Christus, soos Romeine 14 vers 23 ook sê. ' $n$ Goeie handelwyse is nie die somtotaal van 'n aantal afsonderlike, losstaande "werke" nie, maar dit 
vloei voort uit 'n volgehoue en duursame lewenstyl ("Disposition"). Goeie werke is vir Luther onlosmaaklik verbonde aan die geloof en die regverdigmaking deur die geloof alleen. "Goeie werke maak nie die mens goed nie, maar die goeie (dit wil sê "gelowige") mens doen goeie werke". Iemand wat deur die geloof en liefde in Christus ingelyf is, doen as't ware vanself goeie werke, sonder voorskrifte, net so min as wat'n mens aan twee mense wat mekaar liefhet, hoef voor te skryf wat hulle moet doen en sê... Dit is duidelik dat Luther hier kies vir wat in die Engelse literatuur bekend staan as "an ethics of being, disposition" teenoor "an ethics of command". In sy netjiese uiteensetting van Luther se etiek som Roland $H$ Bainton die saak by Luther soos volg op: "God demands not only acts but attitudes". ("Here I stand", 3rd ed 1956, p 174-179). In sy "Von der freyheyt eynes Christen menschen" spreek Luther in hierdie verband die volgende volsinne uit: "Die Woord dra aan die siel al die eienskappe van die Woord oor sodat die siel vertroubaar, vredeliewend, vry, vol van alle goedheid, 'n ware kind van God word... Geen goeie werk kan binne die siel wees, as die Woord en die geloof nie daarin heers nie... Indien iemand nie alreeds 'n gelowige en 'n Christen is nie, het sy werke geen waarde nie." As iemand nie 'n gelowige Christen is nie, "dan is sy "goeie" werke dwase, leë, veroloekte sonde..."

In aansluiting by hierdie motiewe het Stanley Hauerwas in sy boek "Character of Christian Life. A study in Theological Ethics, San Antonio, Trinity University Press, 1975 nog verder as Birch-hulle gegaan. Hy voel dat daar in die moderne teologiese etiek (onder andere by Barth en Bultmann) te veel klem gelê word op drie dinge naamlik-

situasie;

konteks en

beginsels.

Die gemeenskaplike karaktertrek van hierdie rigtings in die etiek is dat hulle, volgens Hauerwas werk met "the metaphor of command". By Bultmann het dit gelei tot 'n etiek waarin iemand in gehoorsaamheid van oomblik-tot-oomblik op diskontinue wyse besluit neem. Hauerwas voel egter vir die handelende self, "the perduring self" wat kontinuiteit aan beide die handelinge én die verantwoordelikheid verskaf. Hierdie soort etiek werk met "the metaphor of character". Die Christelike karakter kom deur die genade tot stand, deur die regverdigmaking in en deur Jesus Christus. Dit kom tot uitdrukking in die heiligmaking; heiligmaking hou kontinuïteit, deurlopendheid, duursaamheid en eenheid in - kortom: "character", dit wil sê die verantwoordelike self, "determined in Christ", waaruit die goeie werke voortvloei. Hierdie blywende self is soos die goeie boom wat die goeie vrugte (die verbygaande goeie dade) voortbring. 
James Luther Adams stem met Hauerwas saam, maar meen dat hy die perspektief ook na die "social and institutional realm" toe moes uitgebrei het: "The figtree of authentic Christian character bears fruit also for social order, as Calvin vigorously insisted ..."

Daar lê 'n sekere element van Bybelse waarheid en 'n groot aantreklikheid in hierdie etiese stelsels wat werk met die "disposisie", "the metaphor of character", met die "category of being" in die proses van "relating the Bible and ethics in Christian life". Ek glo dat ons kerk in die verlede ruim van hierdie prosedure gebruik gemaak het. Ons kerk was altyd, dink ek, ongeneë daartoe om tot in die fynste besonderhede kasuïstiese, metodistiese voorskriffies te gee sodat beslissings oor wat goed en sleg is, al van te vore in kanne en kruike is, sonder dat die lidmaat worstelend, eksistensieel en veral gelowig-beslissend daarby betrokke is. Teenoor so 'n formalistiese, wettiese voorskrif - etiek was ons kerk, dink ek, tereg altyd afwysend. Saam met $N$ H Soë (aw bl 161) het ons altyd gevra:

"Wäre es nicht krankhaft, nach dem Willen Gottes zu fragen"

in elke klein besonderheid van die daaglikse lewe nie? Nie in die sin van Bonhoeffer se "mondige mens" nie, maar in die sin van Calvyn het ons kerk altyd prys gestel op die volwassenheid van die Christenmens wat wel begrens deur die naasteliefde, in gelowige vryheid etiese beslissings maak. Tipies is in hierdie verband wat Calvyn in die Institusie III, 19, 12 sê:

Pii autem hominis est cogitare, sibi liberam in rebus externis potestatem ideo esse concessam quo sit ad omnia charitatis expeditior".

("Maar dit is deel van die vrome mens dat hy moet bedink dat die vrye mag in uitwendige sake om dié rede aan hom toegestaan is, sodat hy in alle pligte van die liefde des te bekwamer mag wees") ... Ons kerk het hierdie etiese houding ten opsigte van die individuele etiek ook ten opsigte van die sosiale etiek gehandhaaf. Ons kerk wou nooit ten opsigte van die openbare en politieke lewe die offisiële protesteerder wees nie, veral nie 'n drukgroep nie. Ons kerk wou altyd eerder gehad het dat sy lidmate in die problematiek van die openbare lewe self hulle weg sou vind of dat hulle as leiers self ten opsigte van dié problematiek besluite sou neem vanuit hulle volwassenheid as gelowiges wat gevorm is deur die regte verkondiging van die Woord.

Maar by al die positiewe aspekte van hierdie oplossingswyse van die basiese probleem van die Christelike Etiek om die Bybel funksioneel te betrek op die Christelik-etiese besluitneming en lewe, moet daar ook op 'n hele aantal basiese punte ernstige vrae gestel word.

Eerstens: Wanneer "disposisie" en "karakter" historiese beslag 
kry en deur die gemeenskap aanvaar word, dan word dit "sede" genoem. Veral in die Ou Testament kry ons die feit dat die gedurige omgang met God en sy Woord ingang vind in (en deel word van) die hart en lewe van die gelowiges sodat dit 'n "gelowige lewenstyl" word. "Lewenstyl" (ook "gelowige lewenstyl") is egter die manier waarop mense aan belewenisse en ervarings vorm gee. Vormgewing hang egter van die menslike aard (byvoorbeeld sy psigologiese instelling) en van die menslike situasie (byvoorbeeld kultuur, geskiedenis en ontwikkelingspeil) af. Dit bring verskeidenheid in die vormgewing mee; veral met die verloop van tyd kan één en dieselfde saak op twee, drie of meer maniere (wat almal " $e g^{\text {" }}$ is) belewe word, terwyl die maniere wat vorm en selfs inhoud betref, baie van mekaar verskil. $R$ Schippers het in sy uitmuntende monografie oor dié saak aangetoon hoedat, selfs in streng behoudende kringe, die gelowige sedes aansienlik gewissel het ("De Gereformeerde Zede", Kampen 1954). Uiteraard bring dit mee dat die normatiwiteit van die sede (en daarmee van die "disposisie" en "karakter") baie sterk geproblematiseer en gerelativeer word. Daar sal altyd onthou moet word dat sede (ensomeer) nooit die Woord self is nie, maar altyd slegs belewenis van die Woord. Hierdie belewenis is belangrik, selfs noodsaaklik, maar is slegs normatief in die sin van 'n norma normatata ('n norm wat self ook gemeet moet word aan die Norm) en nooit van ' $n$ norm normans (dié Norm) nie. Daar sal telkens weer na dié Norm, die Heilige Skrif, teruggegryp moet word. Maar dan word dit duidelik dat aan "the metaphor of command" (met al sy fasette van konteks, beginsels, situasie en gebod) prioriteit begin verleen word bó "the metaphor of character".

Tweedens: Binne die etiese model van "disposisie" en "karakter" skuil daar 'n verdere gevaar (wat met bostaande saak saamhang), naamlik dat die volwasse verantwoordelike Christen stelselmatig al hoe meer dinge na sy eie goeddunke kan begin beoordeel. Die uiteinde is dan dat ten slotte feitlik die ganse lewe onttrek word aan die normatiewe gebod en die gehoorsaamheid teenoor God.

Uit bostaande twee punte van kritiek het dit duidelik geword dat ons nie sonder meer die etiek van "the metaphor of character and disposition" (waarvan ons ook sterk elemente by beide Luther en Calvyn het) wil afskryf nie. Maar net soos ons in die geval van die verbandlegging tussen die historiese stof van die Bybel en die lewe, prioriteit aan die duidelike definitiewe voorskrif bó die historiese voorbeeld gegee het, net so wil ons in 'n sekere sin voorkeur gee aan die "metaphor of command", bokant "the metaphor of character and disposition". My standpunt is dat daar geen "ethics of being" kan wees, sonder dat daarmee ook 'n "ethics of command and doing" verbonde is nie.

Uit hierdie standpunt vloei 'n hele verdere probleemkompleks 
voort wat ons nie binne die bestek van hierdie artikel kan uitwerk nie. Ons stip daarom slegs die volgende elemente van hierdie probleemkompleks aan:

Die eerste vraag is, hoe moet ons die Bybelse "voorskrif" (wet, gebod) verstaan en hanteer? Ook die Skrifgeleerdes en Fariseërs se formele program was om alle fasette van die lewe te stel onder die tug van Gods Woord. Volgens Lukas 11 het Jesus nie hierteen beswaar nie (vers 42 - "hierdie dinge behoort julle te doen"). Die beswaar van Jesus is egter teen hulle beskouing oor en hantering van die Wet van God gerig en wel ten opsigte van twee verbande, naamlik:

dat hulle die Wet formalisties opvat, as voorskrif wat slegs uiterlik nagekom moet word sonder dat die innerlike gesindheid van die dader daar bykom (Luk 11 vers 39-40), en

dat hulle die Wet wetties opvat, slegs as voorskriftelike wet sonder om die evangeliese en profetiese perspektiewe daarby te betrek. So stel hulle die lewe slegs onder die tug en nie óók onder die troos van Gods Woord nie. Die Fariseërs maak die profete dood en bou vir hulle grafte (Luk 11:47-51) deur hulle dood te swyg.

Uit bostaande is dit duidelik dat in ' $n$ "ethics of command" die "gebod" en "verbod" daarin nie formalisties en wetties opgevat sal mag word nie, maar dat hierdie etiek voluit gesindheids-etiek (geloof Rom 14:23 én liefde - Rom 13:8-10) moet wees, terwyl ook die profetiese en evangeliese perspektiewe ten volle verdiskonteer sal moet word. Dit sal ook geen verdienste-etiek kan wees nie, maar binne die Protestantse visie, gegrond op Skrifgedeeltes soos Romeine 3 vers 28, Galate 2 vers 16 en Efesiërs 2 vers 8, 9, sal dit voluit dankbaarheidsetiek moet wees (Rom 13:8-10; Matt 22: 34-40). Verder sal die pneumatologiese motief ook sy volle gewig moet kry, want dit is die Gees wat lewendig maak, ons in 'n nuwe lewe laat wandel en in die hele waarheid lei (byvoorbeeld Joh 6:63; II Kor 3:6; Rom 6:4, 18, 19; Joh 16:13-15).

Die laaste saak wat ons wil noem, betref die wyse waarop 'n lewensaktiwiteit waaroor die Bybel hom nie direk uitspreek nie, (soos byvoorbeeld rook, dans, kaartspel, lotery, vryetydsbesteding ensovoorts) in 'n etiek wat werk met "the metaphor of command" onder ' $n$ duidelike voorskrif soos een van die Tien Gebooie tuisgebring kan word.

Die eerste eis wat ons wil stel, is dat die saak waaroor dit gaan (byvoorbeeld wat verdedigingsobligasies is en wat die wyse van toedeling is en impliseer ook ten opsigte van ander ekonomiese aktiwiteite) uiters noukeurig nagegaan moet word. Dit is nie ' $n$ spesifiek teologiese aktiwiteit nie en die Christelike Etiek sal 
moet leer om baie goed en geduldig na deskundiges op elke betrokke gebied te luister voordat dit praat. Hoewel daar in die diskussie verlede jaar oor die aangeleentheid van die Verdedigingsobligasies óók verkeerde Skrifgebruik was, is die eintlike foute veral gemaak toe daar oor die aard van die obligasies en die toedelingswyse gepraat is. Ek begin al hoe meer oortuig raak dat daar in die Christelike Etiek die meeste gesondig word, nie aan die kant van die Skrif en Skrifgebruik nie, maar aan die kant van die noukeurige en objektiewe vasstelling van die sake wat beoordeel moet word.

Eers ná die objektiewe bepaling van die ware wese en aard van die saak wat beoordeel moet word, kom die vraag na vore van wat uit die Bybel (veral watter duidelike voorskrif) daarop van toepassing is. Hier sal veral sake soos goeie Skrifkennis van groot belang wees. 'n Bybels-legitieme wyse om te vra of die rookgewoonte geoorloof is of nie, kan wees om dit byvoorbeeld onder die eerste gebod tuis te bring. Maar of iemand in werklikheid van rook ' $n$ afgod maak of nie, kan nie algemeen beslis word nie. Dit kan die geval vir één mens wees, maar nie die geval in die lewe van 'n ander mens nie. Of dit so is, sal elkeen met sy eie gewete voor God moet beslis. Die kerklike prediking kan net die saak objektief beskryf en die vraag stel. Op hierdie wyse gaan die etiek wat werk met "the metaphor of command" oor na die etiek wat werk met "the metaphor of disposition".

Dit het egter duidelik geword dat hierdie hele aangeleentheid van die prioriteit van 'n Christelike Etiek wat werk met "the metaphor of command", baie fasette het en baie ingewikkelder is as selfs die aanduidings van die probleme hierbo laat blyk. Dit vra na uitvoeriger wetenskaplike uitwerking. 